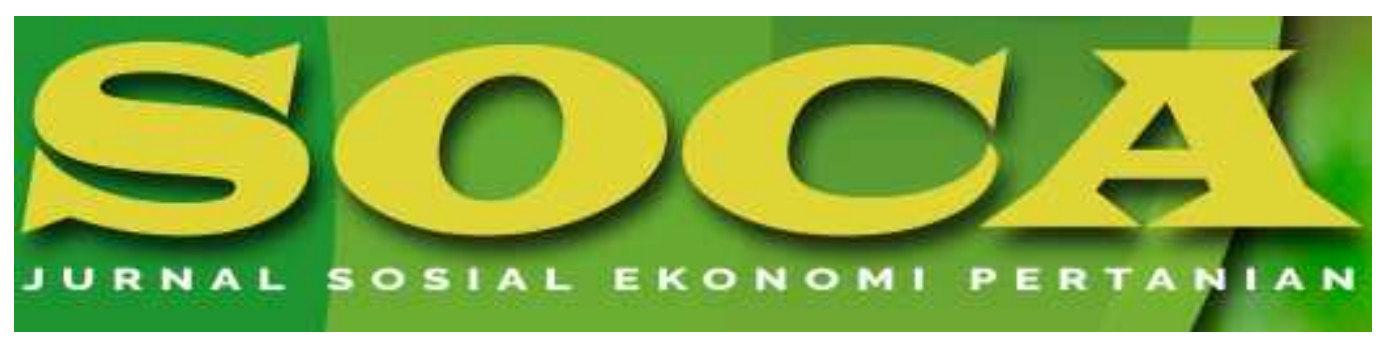

https://ojs.unud.ac.id/index.php/soca

\title{
FAKTOR-FAKTOR PENDUKUNG KEBERLANJUTAN USAHATANI KOPI ARABIKA DI PROVINSI BALI
}

\author{
Ida Ayu Listia Dewi dan I Made Sudarma \\ Program Studi Agribisnis, Fakultas Pertanian, Universitas Udayana, Denpasar, Bali \\ Email korespondensi: listiadewi60@unud.ac.id dan sudarmaimade@yahoo.com \\ Telepon/HP: 082144907558, 08123985990
}

Kata Kunci:
Keberlanjutan,
kopi Arabika,
usahatani,
pendapatan.

Kata Kunci:

Keberlanjutan, usahatani, pendapatan.

\section{Abstrak}

Kopi merupakan andalan ekspor Bali. Potensi pengembangan lahan usahatani kopi Arabika di Bali belum dimanfaatkan. Namun produktivitas hasil kopi Arabika Bali masih rendah. Jumlah petani kopi makin berkurang. Keberlanjutan usahatani Kopi Arabika Bali terancam. Akibatnya sumber pendapatan daerah berkurang. Penting mempertahankan keberlanjutan usahatani kopi Arabika Bali. Tujuan Penelitian ini untuk mengetahui faktor-faktor pendorong keberlanjutan usahatani kopi Arabika di Bali. Lokasi penelitian ditentukan dengan metode purposive. Lokasi penelitian merupakan sentra produksi kopi Arabika di Provinsi Bali. Metode pengumpulan data yang dipergunakan dalam penelitian ini adalah surve, wawancara, studi dokumentasi, dan studi pustaka. Instrument penelitian adalah kuesioner. Metode penentuan jumlah sampling berdasarkan rumus Slovin dengan tingkat eror sebesar $15 \%$ yaitu 52 petani. Metode penentuan sampling berdasarkan random sampling. Analisis dimensi ekonomi menggunakan pendekatan pendapatan usahatani, dimensi sosial, lingkungan, dan teknologi menggunakan pendekatan analisis faktor konfirmatori. Hasil penelitian menunjukkan bahwa dimensi ekonomi dilihat dari pendapatan usahatani kopi Arabika di Bali tahun 2019 per luas rata-rata lahan garapan petani $(0,86 \mathrm{ha})$ sebesar Rp 22.820.376. Kontribusi pendapatan usahatani kopi Arabika di Bali terhadap pendapatan keluarga adalah sebesar 69,07\%. Pengalaman Berusahatani (X22), umur petani (X20), dan pendidikan petani (X21) merupakan komponen Faktor Sosial. Pembuatan rorak (X13), Jumlah Anggota keluarga (X23), melakukan penanaman kembali (X12), penggunaan bibit lokal bermutu (X11), petani mengetahui kondisi lahannya (X10) mewakili Faktor 
Lingkungan. Penggunaan penaung (X14), umur tanaman (X5), penggunaan air bersih (X9), dan panen petik merah (X19) merupakan komponen pembentuk Faktor Teknologi.

FACTORS SUPPORTING SUSTAINABILITY OF ARABIKA COFFEE IN BALI PROVINCE

\section{Keywords:}

Sustainability, Arabica coffee, farming, income.

\begin{abstract}
Abstrak
Coffee is the mainstay of Balinese exports. But the productivity of Balinese Arabica coffee is still low. The sustainability of Bali Arabica Coffee farming is threatened. The purpose of this study was to determine the factors driving the sustainability of Arabica coffee farming in Bali. The research location is the Arabica coffee production center in Bali Province. The method of determining the number of sampling based on the Slovin formula with an error rate of $15 \%$ is 52 farmers. The method of determining sampling is based on random sampling. The economic dimension shows that Arabica coffee farm income in Bali in 2019 per average area of arable land by farmers (0.86 ha) is $R p$ 22,820,376. Contribution of income from Arabica coffee farming in Bali to family income is 69.07\%. Farming Experience (X22), farmer age (X20), and farmer education (X21) are components of Social Factors. Making rorak (X13), number of family members (X23), replanting (X12), use of quality local seeds (X11), farmers know the condition of their land $(X 10)$ representing environmental factors. The use of shade (X14), plant age (X5), use of clean water (X9), and harvesting of red picks (X19) are the components forming the Technology Factor.
\end{abstract}

How to Cite (APA 6 ${ }^{\text {th }}$ Style):

Dewi, I. A. L., \& Sudarma, I. M. (2020). Faktor-Faktor Pendukung Keberlanjutan Usahatani Kopi Arabika di Provinsi Bali. SOCA: Jurnal Sosial Ekonomi Pertanian, 14(1), 158-168.

https://doi.org/https://doi.org/10.24843/SOCA.2020.v14.i01.p13

\section{PENDAHULUAN}

Kopi merupakan andalan Indonesia dalam perdagangan dunia. Menurut Pitoko (2018) Indonesia merupakan negara urutan keempat penghasil kopi setelah Brasil, Vietnam, dan Kolobia. Produktivitas dan kualitas usahatani kopi di Indonesia masih lebih rendah dibandingkan ketiga negara tersebut. Menurut Ditjenbun Pertanian (2016) rendahnya produktivitas dan kualitas hasil produksi kopi dipengaruhi oleh sebagian besar perkebunan kopi yang ada di Indonesia merupakan kopi perkebunan rakyat. Banyak petani kopi berbudidaya tidak sesuai dengan panduan good agriculture practice (GAP). Sejalan dengan pemikiran Marindra (2019) yang menyatakan bahwa petani kopi rakyat di Lampung yang belum tersertifikasi umumnya belum menjalankan teknik budidaya secara baik dan benar, sehingga 
mereka menghasilkan kopi dengan kualitas asalan yang hanya mampu dijual pada pasar lokal dengan harga yang relative rendah. Mereka juga belum memahami pentingnya keberlanjutan usahatani kopi, sehingga mereka belum mampu menerapkan prinsip-prinsip keberlanjutan sosial, lingkungan dan teknologi.

Kopi juga menjadi salah satu produk andalan Bali dalam perdagangan lokal, antar pulau, sampai ekspor. Salah satu jenis kopi yang diekspor Bali adalah kopi Arabika. Kopi merupakan andalan Bali sebagai sumber pendapatan daerah, juga mengalami penurunan produktivitas. Menurut Dinas Tanaman Pangan, Hortikultura, dan Perkebunan Provinsi Bali (2018) produktivitas Kopi Arabika menurun setiap tahunnya dari tahun 2015 sampai tahun 2017 yaitu 561, 539, dan $457 \mathrm{~kg} / \mathrm{Ha} /$ tahun. Kondisi lain juga menunjukkan bahwa jumlah petani kopi Arabika semakin berkurang setiap tahunnya dari tahun 2015 sampai 2017 yaitu 16.810, 16.745, dan 16.130 orang petani. Banyak petani kopi Arabika beralih produk usahatani menjadi non kopi seperti jeruk juga produk hortikultura. Ini disebabkan oleh harga jual yang tidak sesuai dengan pengeluaran petani untuk usahatani kopi Arabika. Bila dibandingkan dengan produksi kopi Arabika di Sulawesi Selatan diperkirakan sebesar 7000 ton dengan daya saing yang rendah, akibat kurangnya pengetahuan petani terhadap penanganan panen dan pasca panen sehingga kualitas produk menjadi rendah (Awaluddin, dkk, 2018).

Pada sumber yang sama lebih lanjut dijelaskan bahwa dilihat dari potensi, pengembangan usahatani kopi Arabika masih memiliki potensi untuk dikembangkan. Potensi areal kopi Arabika di Bali sebesar 23.485 Ha, dan baru diusahakan sebesar 12.228 Ha, sehingga tersisa 11.257 Ha. Potensi ini penting di kembangkan untuk menggiatkan perekonoian nasional dan juga meningkatkan kesejahteraan petani kopi Arabika di Bali. Bertolak dari hal tersebut maka usahatani kopi Arabika di Provinsi Bali penting dijaga keberlanjutannya.

Pada dasarnya konsep keberlanjutan mengandung tanggungjawab moral bagi seorang produsen termasuk petani untuk memastikan bahwa aktivitas produksinya akan terus dapat berlanjut sampai ke generasi-generasi berikutnya. Menurut Brklacich, dkk (1992) sistem pertanian berkelanjutan mengandung pengertian bahwa dalam jangka panjang sistem tersebut harus mampu mempertahankan bahkan meningkatkan kualitas lingkungan, menyediakan insentif sosial dan ekonomi pada semua pelaku dalam sistem produksi, dan mampu berproduksi secara cukup dan masing-masing penduduk memiliki akses terhadap produk yang dihasilkan tersebut. Menurut SEARCA, 1995 (dalam Budiasa, 2011) mengatakan bahwa Kreteria pertanian berkelanjutan meliputi: (a) kelayakan ekonomi, (b) ramah lingkungan, (c) adil secara sosial, (d) cocok/selaras dengan budaya setempat, dan (e) sistem pertanian berkelanjutan berbasis pengetahuan yang holostik/kompresensip/ multi-disiplin, serta mempertimbangkan interaksi dinamis antara aktivitas on-farm, dan non on-farm. Teknologi tepat guna, kebijakan, dan pengelolaan sumberdaya sesuai dengan keunggulan kompereratif dan kompetitif suatu wilayah sangat diperlukan untuk mewujudkan tujuan pembangunan pertanian berkelanjutan (Adnyana, 2001).

Dalam kaitannya dengan keberlanjutan produksi kopi, menurut Kementrian Pertanian Direktorat Jendral Perkebunan (2014) dewasa ini berkembang bermacammacam praktek perdagangan yang diinisiasi oleh konsumen kopi. Konsumenkonsumen tertentu menghendaki kopi bersertifikat seperti Fairtrade, Utz Certified, 
Organic, Common Code for Coffee Community (4C), Rainforest Alliance, Coffee and Farmer Equity (CAFE) Practices (Starbucks), dan Bird Friendly. Semua sistem tersebut pada dasarnya menekankan pada kejelasan asal-usul (traceability) dan keberlanjutan (sustainability). Prinsip kopi keberlanjutan yaitu: environmentally sustainable; economically viable; dan socially acceptable.

Keberlanjutan kopi Arabika di Bali dapat terpenuhi dengan mengikuti dimensi keberlanjutan pada konsep pertanian berkelanjutan. Kegiatan produksi pertanian bisa berlanjut bila dalam kegiatan usahatani memperhatikan lingkungan. Keberlanjutan usahatani dapat terwujud bila petani sebagai pelaku usaha memperoleh keuntungan. Keberlanjutan bisa terlaksana bila usaha pertanian ditunjang penggunaan teknologi yang tepat guna. Keberlanjutan dapat diwujudkan bila masyarakat sosial dan kelembagaan menerima dan mendukung usaha tersebut.

Melihat penjelasan tersebut maka dapat dikatakan bahwa keberlanjutan usahatani kopi Arabika sangat penting diwujudkan untuk meningkatkan pendapatan daerah dari salah satu komuditi unggulan Bali. Keberlanjutan usahatani kopi Arabika Bali ditentukan oleh faktor ekonomi, sosia, ekologi, dan teknologi. Untuk dapat melakukan evaluasi terhadap keberlanjutan usahatani kopi Arabika di Bali maka dimensi-dimensi keberlanjutan harus diidentifikasi lebih dahulu. Berdasarkan hal tersebut maka tujuan penelitian ini adalah untuk yaitu mengidentifikasi besar pendapatan usahatani kopi Arabika di Bali pada tahun 2019 dan faktor-faktor yang mendorong keberlanjutan usahatani kopi Arabika di Bali diluar dimensi ekonomi.

\section{METODE PENELITIAN}

Penelitian akan dilakukan di Desa Catur, Kecamatan Kintamani, Kabupaten Bangli. Lokasi penelitian ditentukan dengan metode purposive yaitu pemilihan lokasi penelitian dengan sengaja berdasarkan pertimbangan merupakan sentra produksi kopi Arabika di Provinsi Bali. Waktu penelitian dilaksanakan adalah dari Bulan Juni sampai Agustus 2019. Metode pengumpulan data yang dipergunakan dalam penelitian ini adalah surve, wawancara, studi dokumentasi, dan studi pustaka dengan instrument penelitian berupa kuesioner.

Data kuantitatif dalam penelitian ini adalah harga jual kopi Arabika di tingkat petani per kg, kuantitas produk yang dijual per musim panen, biaya produksi per tahun, dan pendapatan petani dari non kopi. Sedangkan data kualitatif dalam penelitian ini adalah dimensi yang berhubungan dengan dimensi social, lingkungan, dan teknologi. Data pada dimensi social, lingkungan, dan teknologi mempergunakan data ordinal dalam bentuk skala 1 sampai 5 .

Populasi penelitian ini adalah seluruh petani kopi Arabika di Desa Catur, Kecamatan Kintamani, Kabupaten Bangli yaitu sebanyak 599 orang. Metode penentuan jumlah sampling berdasarkan rumus Slovin dengan tingkat eror sebesar $15 \%$ diperoleh jumlah responden 42 orang, tetapi menurut Supriyadi (2014) sampel secara umum pada analisis faktor berkisar antara 50 sampai 100, sehingga jumlah sampel dalam penelitian ini dipergunakan sebanyak 52 petani kopi. Metode penentuan sampling berdasarkan random sampling. 
Setelah Tabulasi mata data akan dianalisis secara deskriptif baik berupa deskriptif kuantitatif ataupun kualitatif, disesuaikan dengan tujuan penelitian. Adapun langkah-langkah analisis data adalah sebagai berikut.

1. Parameter ekonomi dihitung dengan menggunakan rumus pendapatan usahatani tahun berjalan dengan rumus

$$
\Pi=\mathrm{TP}-\mathrm{TC}
$$

Keteranagan:

$\Pi=$ Pendapatan usahatani kopi Arabika di Bali

$\mathrm{TP}=$ Total Penerimaan penerimaan kopi per tahun

$\mathrm{TC}=$ Total Biaya produksi kopi per tahun

$$
\mathrm{TP}=\mathrm{P} \times \mathrm{Q}
$$

Keterangan:

$\mathrm{TP}=$ Total Penerimaan kopi Arabika di tingkat petani per tahun

$\mathrm{P} \quad=\quad$ Harga jual kopi Arabika Gelondong Basah di tingkat petani

$\mathrm{Q}=\quad$ Kuantitas produksi kopi Arabika per tahun

$$
\mathrm{TC}=\mathrm{TVC}+\mathrm{TFC}
$$

Keterangan:

$\mathrm{TC}=$ Total Biaya produksi kopi Arabika per tahun

TVC $=$ Total biaya variabel: biaya TK, pupuk, dan obat

$\mathrm{TFC}=$ Total biaya tetap: penyusutan beralatan, sewa lahan

Kontribusi pendapatan usahatani kopi Arabika dibandingkan dengan pendapatan petani

$$
\text { Kontribusi }=\left(\prod / \text { total pendapatan keluarga petani }\right) \times 100 \%
$$

Setelah memperoleh kedua nilai tersebut maka dilakukan scoring terhadap semua parameter di masing-masing dimensi keberlanjutan.

2. Mengidentifikasi faktor-faktor pendorong keberlanjutan usahatani kopi Arabika menggunakan analisis Faktor Konfirmatori, dengan bantuan program SPSS 13.0.

\section{HASIL DAN PEMBAHASAN}

\section{Dimensi Ekonomi sebagai Faktor Penunjang Keberlanjutan Usahatani Kopi Arabika Bali}

Keberlanjutan usahatani kopi Arabika di Bali didorong dari ada tidaknya manfaat ekonomi yang diterima petani. Petani umumnya akan bertahan melakukan unit usaha bila usaha tersebut memperoleh keuntungan. Usaha yang tidak menjanjikan tentunya akan ditinggalkan oleh petani. Bertolak dari hal tersebut penelitian ini mencoba menganalisa keuntungan usahatani kopi Arabika pada tahun berjalan yaitu tahun 2019, kemudian pendapatan tersebut di bandingkan dengan pendapatan keluarga. Berdasarkan hal tersebut maka disajikan dibawah ini perhitungan pendapatan usahatani Kopi Arabika tahun 2019. 
Tabel 1. Pendapatan Rata-rata Usahatani Kopi Arabika di Bali per LLG Petani Tahun 2019

\begin{tabular}{lr}
\hline Penerimaan & \\
\hline Produksi & 3.929 \\
$\quad$ Harga & 9.567 \\
\hline Total Penerimaan & \\
\hline Biaya & 37.588 .480 \\
Biaya Variabel & \\
\hline Pupuk Kandang Kotoran Sapi & 1.209 .677 \\
Pupuk Kandang Kotoran Ayam & 8.575 .236 \\
Tenaga Kerja & 703.125 \\
Pisau Pangkas & 13.961 .115 \\
\hline Total & 353.417 \\
\hline Biaya Tetap & 806.989 \\
\hline Penyusutan peralatan & 14.768 .104 \\
$\quad$ Perawatan mesin sensor & \\
Total & \\
\hline Total Biaya & \\
\hline Pendapatan & \\
\hline Sumber: diolah dari data primer (2019) & \\
\end{tabular}

Panen kopi Arabika di Bali dilakukan sekali dalam satu tahun. Pendapatan rata-rata usahatani kopi Arabika di Bali tahun 2019 per luas rata-rata lahan garapan petani $(0,86 \mathrm{ha})$ sebesar $\mathrm{Rp} 22.820 .376$. Bila di rata-ratakan per bulan pendapatan usahatani kopi Arabika di Bali menjadi sebesar Rp 1.901.698. Nilai ini bila dipandingkan dengan UMP Bali sebesar Rp 2.297.968,70 masih lebih rendah. Ini berarti pendapatan usahatani kopi Arabika di Bali belum memenuhi standar kehidupan yang ditetapkan pemerintah sehingga kesejahteraannya masih digolongkan rendah. Hasil ini berbeda dengan hasil penelitian Imsar (2018) besar pendapatan bersih rata-rata petani Kopi Arabika Gayo Sumatra Utara per hektar dalam sekali panen yaitu sebesar Rp 19.850.161 sedangkan jika dihitung pertahun nya Rp 39.700.322 atau sekitar Rp 3.308.360,17 per bulan. Perbedaan pendapatan usahatani ini berbeda karena perbedaan kemampuan produktivitas kopi masingmasing wilayah. Hasil usahatani kopi Arabika sangat tergantung dari spesifikasi lokasi, juga harga jual kopi, dan biaya produksi.

Elemen biaya tertinggi adalah tenaga kerja. Biaya tenaga kerja yang banyak dipergunakan saat kegiatan panen. Sama dengan dengan pernyataan Yuliasmara (2018) bahwa tantangan utama dalam budidaya kopi adalah produktivitas hasil yang rendah, isu perusakan lingkungan, perubahan iklim, tingginya biaya tenaga kerja, dan terbatasnya ketersediaan tenaga kerja. Rata-rata biaya tenaga kerja panen adalah Rp 1.729.519. Periode panen dilakukan selama 3 bulan dari bulan Juni sampai Agustus. Satu periode panen dilakukan tiga sampai empat kali petik. Satu kali petik petani membutuhkan waktu tiga sampai empat hari. Tenaga kerja yang dipergunakan pada kegiatan pemetikan lebih banyak mempergunakan tenaga 
kerja perempuan dan kisaran upah petik per hari antara Rp 60.000 sampai Rp 70.000 .

Bila dilihat dari kontribusi pendapatan usahatani kopi Arabika terhadap pendapatan keluarga petani adalah sebesar 69,07\%. Artinya bahwa pendapatan keluarga ditunjang dari pendapatan usahatani kopi Arabika. Ini memunjukkan bahwa pendapatan dari usahatani kopi Arabika sangat penting artinya bagi kesejahteraan petani.

\section{Faktor-faktor yang Mendorong Keberlanjutan Usahatani Kopi Arabika di Bali Diluar Dimensi Ekonomi}

Faktor pendorong keberlanjutan usahatni kopi Arabika di Bali dianalisis dengan analisis faktor konfirmatori. Terdapat 23 parameter yang dipergunakan dalam menganalisis analisis faktor yaitu ketinggian tempat (X1), kemiringan lahan (X2), jenis penaung (X3), varietas unggul (X4), umur tanaman (X5), penggunaan pupuk (X6), serangan hama penyakit (X7), pengolahan tanah (X8), ketersediaan sumber air bersih (X9), analisa kondisi lahan (X10), pembibitan sendiri (X11), melakukan penanaman kembali (X12), pembuatan rorak (X13), penggunaan tanaman penaung (X14), teknik penggulmaan (X15), pemangkasan (X16), evaluasi penyakit dan penanganannya (X17), penggunaan obat-obatan (X18), panen petik merah (X19), umur petani (X20), pendidikan petani (X21), pengalaman petani (X22), dan jumlah anggota keluarga (X23). Analisis faktor konfirmatori dibantu oleh SPSS 20.

Periode pertama Uji KMO adalah 0,515 dan Bartlett's Test sebesar 356,804 pada sig. 0,000. Menurut Supriyadi (2014) Nilai Uji KMO >0,5 menandakan analisis faktor dapat dilakukan. Namun ada beberapa parameter yang tidak memenuhi persyaratan kelayakan nilai MSA (measures of sampling adequacy) $>0,5$ yang artinya parameter tersebut tidak memenuhi ketentuang analisis faktor dan parameter tersebut harus dibuang.

Parameter yang tidak memenuhi persyaratan yaitu sebanyak 10 antara lain $\mathrm{X} 1, \mathrm{X} 2, \mathrm{X} 3, \mathrm{X} 4, \mathrm{X} 6, \mathrm{X} 7, \mathrm{X} 8, \mathrm{X} 15, \mathrm{X} 16$, dan X17. Setelah semua variabel yang nilai $\mathrm{MSA}<0,5$ dihilangkan dalam analisis uang dengan 13 parameter yang layak. Analisa ke dua menghasilkan nilai KMO bernilai 0,590 and Bartlett's Test dan Nilai Antiimage Matrices sebesar 159,663 pada sig. 0,000. Pada tahap ini masih terdapat satu parameter yang tidak memenuhi syarat dan harus dikeluarkan karena nilai $\mathrm{MSA}<0,5$, parameter tersebut adalah X18. Analisis tahap tiga setelah nilai X18 dikeluarkan menghasilkan nilai KMO 0,595 dan nilai Bartlett's Test dan Anti-image Matrices; 155,042 pada sig. 0,000. dan semua parameter sisanya (X5, X9, X10, X11, $\mathrm{X} 12$, X13, X14, X19, X20, X21, X22, dan X23) dapat diproses lebih lanjut.

Dari 12 parameter yang memenuhi syarat uji terbentuk tiga faktor utama yang nilai eigentvalue $>1$. Besarnya prosentase variasi Faktor-1 adalah 19,694\%, Faktor-2 adalah 17,981\%, dan Faktor-3 adalah 17,095\%. Ini berarti bahwa Faktor1 mampu memberi informasi sebesar 19,694\%, Faktor-2 dan Faktor-3, masingmasing memberikan informasi sebesar 17,981\% dan 17,095\%. Total variasi sebesar $54,770 \%$. Ini berarti data yang diolah memberi informasi sebesar 54,770\%. Nilai ini kurang dari $60 \%$, karena ada satu faktor yang dieliminasi. 
Berdasarkan tiga faktor yang terbentuk, maka masing-masing faktor memiliki komponen utama pembentuk faktor, Komponen utama tersebut dapat dilihat pada tabel berikut.

Tabel 2. Komponen Utama Pembentuk Faktor-faktor Pendorong Keberlanjutan Usahatani Kopi Arabika di Bali

\begin{tabular}{ccccccc}
\hline & \multicolumn{2}{c}{ Faktor-1 } & \multicolumn{2}{c}{ Faktor-2 } & \multicolumn{2}{c}{ Faktor-3 } \\
\cline { 2 - 7 } No & Parameter & $\begin{array}{c}\text { Nilai } \\
\text { Komponen } \\
\text { Matrik }\end{array}$ & Parameter & $\begin{array}{c}\text { Nilai } \\
\text { Komponen } \\
\text { Matrik }\end{array}$ & Parameter & $\begin{array}{c}\text { Nilai } \\
\text { Komponen } \\
\text { Matrik }\end{array}$ \\
\hline 1 & X22 & 0,942 & X13 & O,805 & X14 & 0,770 \\
2 & X20 & 0,854 & X23 & 0,658 & X5 & 0,606 \\
3 & X21 & 0,559 & X12 & 0,655 & X9 & 0,596 \\
4 & & & X11 & 0,553 & X19 & 0,560 \\
5 & & & X10 & 0,517 & & \\
\hline
\end{tabular}

Sumber: diolah dari data primer, (2019)

Berdasarkan tabel di atas dapat diketahui komponen utama pembentuk ketiga faktor yang terbentuk. Komponen utama Faktor-1 adalah pengalaman perusahatani kopi Arabika (X22), umur petani (X20), dan pendidikan petani (X21). Berdasarkan komponen utama yang tersusun pada Faktor-1 maka faktor ini diberi nama Faktor Sosial. Komponen utama pembentuk Faktor-2 adalah pembuatan rorak (X13), jumlah anggota keluarga (X23), penanaman kembali (X12), pembiatan bibit (X11), dan evaluasi kondisi lahan (X10). Berdasarkan komponen utama pembentuk Faktor-2, maka faktor ini diberi nama Faktor teknis/Lingkungan. Komponen utama pembentuk Faktor-3 adalah penggunaan tanaman penaung (X14), umur tanaman (X5), ketersediaan sumber air bersih (X9), dan panen petik merah (X19). Berdasarkan komponen pembentuk Faktor-3, maka faktor ini diberi nama Faktor Teknologi.

Keberlanjutan usahatani kopi Arabika dapat dipastikan tercapai apabila petani pelaku kegiatan memperoleh manfaat ekonomis yang layak untuk kesejahteraan keluarganya. Petani tidak dapat memperoleh manfaat ekonomis yang layak secara mudah, harus ada usaha, kemampuan, dan kemauan untuk membuat suatu perubahan dan trobosan-trobosan dari apa yang sudah pernah dilakukan. Mereka harus ulet, gigih, dan aktif mencari informasi-informasi untuk peningkatan hasil. Karakteristik ini terpenuhi bila petani memiliki tingkat pendidikan yang baik. Petani usia muda juga cenderung lebih aktiv dalam pengembangan usahanya. Mereka lebih gigih dan lebih mau menerima inovasi-inovasi baru dibandingkan dengan petani golongan usia tua. Lama tidaknya pengalaman petani berusahatani kopi Arabika membuat mereka lebih memahami tindakan apa yang menguntungkan dan merugikan usahatani mereka.

Pembuatan rorak menurut petani sangat membantu petani dalam menjaga kualitas unsur hara tanaman. Pada saat hujan, pupuk yang disebarkan petani disekitar tanaman tidak hanyud terbawa air hujan. Selain itu pembuatan rorak juga mampu mengisilasi perkembangan hama dan penyakit, ini pula yang menyebabkan di lokasi penelitian serangan hama penyakit sangat sedikit. Penanaman kembali merupakan suatu tindakan rehabilitas kualitas lahan. Tanaman yang memasuki 
usia produksi membutuhkan unsur hara yang banyak, sehingga di akhir masa produktivitas tinggi ketersediaan hara di dalam tanah juga semakin sedikit, untuk itu perlu dilakukan perbaikan kualitas lahan dengan mengganti tanaman dengan yang baru, tanaman yang cocok untuk memperbaiki unsur hara lahan. Umumnya petani tidak langsung mengganti dengan tanaman kopi arabika yang masih muda, tetapi menanami dengan tanaman lain seperti jeruk atau tanaman hortikultura. Penanaman kopi Arabila mulai dilakukan setelah dua sampai tiga tahun kemudian. Melakukan evaluasi kondisi lahan sangat penting dilakukan petani untuk mengetahui kandungan unsur hara tanah dan mengetahui tindakan apa yang harus mereka lakukan untuk memperbaikinya. Penggunaan bibit unggul yang berasal dari daerah lokal sangat penting bagi petani. Bibit lokal yang datang dari daerah lain seringkali tidak memberikan hasil yang sesuai harapan mereka. Perbedaan kondisi geografis suatu wilayah berdampak pada beragamnya varietas tanaman yang dihasilkan. Keunggulan varietas tersebut kembali sangat tergantung dari kondisi geografis tanaman tersebut ditanam. Varietas yang unggul di suatu daerah belum tentu berhasil di daerah lain. Ini lah yang menjadi keyakinan petani pada umumnya sehingga mereka lebih memilih melakukan pembibitan sendiri. Jenis varietas yang tersebar di Kintamani sudah merupakan varietas yang berkategori unggul sesuai dengan rekomendasi dari MPG yaitu Kopyol, S 795, Kartika, dan USDA. Saat ini ada varietas baru yang masuk di wilayah ini yang berasal dari luar provinsi Bali yaitu bibit Sigarurutang. Ada beberapa petani yang bersedia menerima bantuan bibit baru tersebut dan sebagian besar tidak. Petani biasanya akan menerima suatu inovasi baru bila inovasi tersebut mampu menunjukkan hasil yang lebih baik. Bibit yang unggul akan memberikan hasil yang baik tentunya petani akan bertahan pada suatu usaha yang memberikan hasil yang baik.

Teknologi menjadi elemen penting dalam kesuksesan dan keberlanjutan usaha. Pengaturan umur tanaman sangat berpengaruh pada hasil produktivitas tanaman. Pada umumnya setelah tanaman berumur 20 tahun tanaman tersebut sudah tidak memberikan keuntungan bagi usahatani kopi Arabika. Petani sangat dianjurkan melakukan pergantian tanaman setelah tanaman berumur 20 tahun, tetapi pada kenyataannya secara umum di lapangan umur tanaman kopi Arabika petani di Bali ditemukan lebih banyak berusia di atas umur 20 tahun. Pengaturan tanaman penaung sangat menentukan produksi hasil. Tanaman kopi Arabika rentan dengan kondisi ekstrim sehingga memerlukan peneduh. Pemilihan jenis tanaman yang dijadikan peneduh juga harus dipilih yang memberikan manfaat baik bagi tanaman kopi, seperti lamtoro, sengon, dan jeruk. Tanaman penaung juga harus dirawat dan dipangkas cabang-cabangnya. Pengaturan pemangkasan didasarkan pada waktu yang tepat disesuaikan dengan bulan-bulan pembungaan tanaman kopi Arabika di Bali. Bagian mana dari tanaman penaung yang harus dipangkas juga harus di atur seberapa banyak yang harus di pangkas itu juga harus diperhatikan. Tanaman kopi Arabika tidak memerlukan penyiraman khusus karena sudah cukup diperoleh dari air hujan dan embun yang jatuh secara alami. Namun pembersihan dan perawatan peralatan dan penanganan pasca panen sangat memerlukan ketersediaan air bersih. Cara panen petik merah sangat penting dilakukan karena panen dengan petik merah adalah sistem panen yang dipetik saat buah matang secara sempurna, sehingga hasil yang diperoleh menjadi optimal. Cita rasa kopi akan muncul pada produksi yang berasal dari buah matang secara 
sempurna. Ini yang menyebabkan harga jual buah berkualitas lebih tinggi dari buah yang tidak berkualitas. Harga jual biji kopi Arabika gelondong merah di tingkat petani di Kintamani adalah mencapai kisaran Rp 9.000 sampai Rp 10.000 per kg. Sedangkan harga jual biji kopi yang dipanen secara raut (sembarang) di tingkat petani hanya di hargai sebesar Rp 5.000. Ini yang menyebabkan di lokasi penelitian semua petani sudah menerapkan sistem petik merah saat melakukan panen.

Hal senada diungkuapkan dalam penelitian Saragih (2018) bahwa determinan produksi yang dominan dari aspek ekologis untuk meningkatkan produksi kopi arabika spesiati di wilayah dataran tinggi Sumatera Utara adalah variabel pemangkasan tanaman kopi arabika dan pengendalian hama penggerek buah kopi. Aspek ekologis lainnya yaitu variabel pohon pelindung, pupuk organik, dan kegiatan konservasi lahan tidak berpengaruh signifikan sebagai determinan produksi kopi arabika. Sama dengan dengan pernyataan Yuliasmara (2018) bahwa tinggirendahnya produktivitas hasil panen kopi Arabika dipengaruhi oleh banyak hal antara lain klon/bibit unggul, pemupukan, sistem pemangkasan, pengelolaan tanaman penaung, pengendalian hama penyakit, dan pengairan.

\section{KESIMPULAN DAN SARAN}

\section{Simpulan}

Dimensi ekonomi menunjukkan bahwa pendapatan usahatani kopi Arabika di Bali tahun 2019 per luas rata-rata lahan garapan petani $(0,86$ ha) sebesar Rp 22.820.376. Dilihat dari kontribusi pendapatan usahatani kopi Arabika di Bali terhadap pendapatan keluarga adalah sebesar 69,07\%. Pengalaman Berusahatani (X22), umur petani (X20), dan pendidikan petani (X21) merupakan komponen Faktor Sosial. Pembuatan rorak (X13), Jumlah Anggota keluarga (X23), melakukan penanaman kembali (X12), penggunaan bibit lokal bermutu (X11), petani mengetahui kondisi lahannya (X10) mewakili Faktor Lingkungan. Penggunaan penaung (X14), umur tanaman (X5), penggunaan air bersih (X9), dan panen petik merah (X19) merupakan komponen pembentuk Faktor Teknologi.

\section{Saran}

Penanaman ulang dengan tanaman kopi Arabika muda memang perlu dilakukan untuk dapat meningkatkan kuantitas produksi masing-masing tanaman kopi Arabika di lokasi penelitian, mengingat sebagian besar umur tanaman kopi Arabika petani di lokasi penelitian lebih dari 20 tahun. Tetapi banyak petani tidak melakukan peremajaan tanamannya, karena petani tidak berani kehilangan sumber pemasukan utamanya. Ada baiknya petani disarankan untuk melakukan peremajaan tanaman kopi Arabika secara bertahap sedikit demi sedikit, atau dengan menerapkan teknologi grafting (sambung atas atau sambung samping) sehingga produksi hasil lebih cepat diperoleh.

\section{UCAPAN TERIMA KASIH}

Penulis mengucapkan terima kasih kepada Dekan Fakultas Pertanian dan Ketua Lembaga Penelitian dan Pengabdian kepada Masyarakat (LPPM) Universitas Udayana atas fasilitasi dalam penelitian dan penulisan artikel ini melalui Bantuan Dana Penelitian PNBP Unud pada skim Penelitian Unggulan Program Studi. 


\section{DAFTAR PUSTAKA}

Adnyana, Made Oka. 2001. Pengebangan Sistem Usaha Pertanian Berkelanjutan. JurnalFAE, 19(2), 38-49.

Awaluddin, Nurareni, dan Mais Ilsan. 2018. Analisis Keberlanjutan usahatani kopi Arabika Bawakareng kecamatan Sinjai Barat Kabupaten Sinjai. Jurnal Agrotek, 2(2), 73-84.

Brklacich, M., Bryant, C.R. and Smith, B. 1991. Review and Appraisal of Concept of Sustainable Food Production Systems. Environ. Management, 15(1),1-1 4.

Budiasa, I Wayan. 2011. Pertanian Berkelanjutan dan Teori Pemodelan. Udayana University Press: Denpasar.

Dinas Tanaan Pangan, Hortikultura dan Perkebunan Provinsi Bali. 2018. Statistik Perkebunan Provinsi Bali Tahun 2017. Dinas TanamanPangan, Hortikultura, dan Perkebunan, Provinsi Bali: Denpasar.

Ditjenbun Pertanian. 2016. Kebijakan Pengembangan Kopi Nasional. Diundup pada: http://www.upacaya.com/kebijakan-pengembangan-kopi-nasional/. Diakses tanggal 29 Januari 2019.

Imsar. 2018. Analisis Produksi Dan Pendapatan Usahatani Kopi Gayo (Arabika) Kabupaten Bener Meriah (Studi Kasus: Desa Pantan Tengah Kecamatan Permata). [Laporan Penelitian]. Medan. Fakultas Ekonomi Dan Bisnis Islam, Universitas Islam Negeri Sumatera Utara.

Kementrian Pertanian Direktorat Jendral Perkebunan. 2014. Pedoman Teknis Budidaya Kopi yang Baik (Good Agriculture Practices /Gap on Coffee). Jakarta.

Marindra, G. 2018. Analisis Keberlanjutan Usahatani Kopi Sertifikasi Common Code for The Coffee Community (4C) di Kabupaten Tanggamus Provinsi Lampung.[Skripsi]. Lampung: Universitas Lampung.

Saragih, J. R. 2018. Aspek Ekologis dan Determinan Produksi Kopi Arabika Spesialti di Wilayah Dataran Tinggi Sumatra Utara. Jurnal Wilayah dan Lingkungan, 6(2), 74-87.

Supriyadi, Edy. 2014. SPSS+Amos Statistical Data Analisis. Jakarta. In Media.

Pitoko, Ridwan Aji. 2018. Strategi Pemerintah Tingkatkan Produksi Kopi dalam Negeri. diunduh: https://ekonomi.kompas.com/read/2018/04/26/225200726/._Diakses tanggal 29 Januari 2019.

Yuliasmara, F. 2018. Budidaya Kopi Berkelanjutan dan ramah Lingkungan. Pusat Penelitian Kopi dan Kakao Indonesia. Diunduh pada http://www.tpsaproject.com/wp-content/uploads/2018-01-16-

Presentation-2-1123.04d.pdf. di akses pada tanggal 10 Januari 2020. 